\title{
The spider fauna of Russia and adjacent regions: a 2009 update
}

\section{Фауна пауков России и прияежащих регионов: обновление 2009 года}

\author{
K.G. Mikhailov \\ К.Г. Михайлов
}

Zoological Museum MGU, Bolshaya Nikitskaya Str. 6, Moscow 125009 Russia. E-mail: mikhailov2000@gmail.com Зоологический музей МГУ, ул. Большая Никитская, 6, Москва 125009 Россия.

KEY WORDS: spiders, Russia, former Soviet Union republics, physiographical areas, fauna, catalogue.

КЛЮЧЕВЫЕ СЛОВА: пауки, Россия, республики бывшего СССР, физико-географические области, фауна, каталог.

ABSTRACT. Recent (2009) calculations of the spider species richness in Russia, and in the former Soviet Union (FSU) republics, as well as in the main physiographical areas are provided as compared to earlier data. As of $31^{\text {st }}$ December 2009, 3,249 spider species were reported from the FSU territories, including 2,297 species from Russia. Updated forecasts of the total spider faunas of the FSU and Russia are given.

РЕЗЮМЕ. В сравнении с данными предыдущих лет, на 2009-й год приведены подсчёты видового богатства пауков России и республик бывшего СССР. По состоянию на 31 декабря 2009 г. с территории бывшего СССР отмечено 3249 видов пауков, с территории России - 2297 видов. Даны обновленные прогнозы общего числа видов пауков в фаунах бывшего СССР и России.

The material presented below is a result of my own project started in 1981, aiming at compiling all available literature data, albeit with some criticism, concerning the spiders of Russia and other post-Soviet republics (former Soviet Union, FSU) since the $18^{\text {th }}$ century. Publication of all material (like the famous "Catalogue of the Russian Spiders" by D.E. Kharitonov [Charitonov, 1932, 1936], comparable with or exceeding in size P. Bonnet's "Bibliographia Araneorum") currently is impossible, first of all due to purely technical reasons. Only a checklist of the spiders together with a bibliographical index covering all literature data as of July 2000 has hitherto been published [Mikhailov, 1997, 1998, 1999, 2000].

This paper updates Russia's spider fauna as of $31^{\text {st }}$ December 2009 and, more generally, reflects changes in the knowledge of FSU spiders. Earlier calculations have been published elsewhere [Mikhailov, 1992, 1997, 2002, 2011, etc.]. An updated bibliographical list is in preparation.
Until now, 3,249 spider species have been reported from the FSU territories (Tables 1, 2). Since the 2000 evaluation, the main increase in species composition is recorded in Linyphiidae $(+106$ species), followed by Gnaphosidae $(+63)$, Lycosidae $(+56)$, Theridiidae $(+35)$, and Salticidae $(+31)$. The increase in species number

Table 1. Species diversity of main spider families, FSU territory.

Таблица 1. Видовое разнообразие основных семейств пауков, территория бывшего СССР.

\begin{tabular}{|l|c|c|}
\hline \multirow{2}{*}{ Family } & \multicolumn{2}{|c|}{$\begin{array}{c}\text { No. of species (percentage is given } \\
\text { in brackets) }\end{array}$} \\
\cline { 2 - 3 } & $\mathbf{2 0 0 0}$ & $\mathbf{2 0 0 9}$ \\
\hline Linyphiidae & $873(30.88)$ & $979(30.13)$ \\
\hline Gnaphosidae & $294(10.40)$ & $357(10.99)$ \\
\hline Salticidae & $307(13.19)$ & $338(10.40)$ \\
\hline Lycosidae & $263(9.30)$ & $319(9.82)$ \\
\hline Thomisidae & $168(5.94)$ & $177(5.45)$ \\
\hline Theridiidae & $132(4.67)$ & $167(5.14)$ \\
\hline Araneidae & $113(4.00)$ & $128(3.94)$ \\
\hline Clubionidae & $99(3.50)$ & $112(3.45)$ \\
\hline Philodromidae & $74(2.62)$ & $92(2.83)$ \\
\hline Dysderidae & $91(3.22)$ & $90(2.77)$ \\
\hline Agelenidae & $54(1.91)$ & $80(2.46)$ \\
\hline Dictynidae & $59(2.09)$ & $71(2.19)$ \\
\hline Tetragnathidae & $43(1,52)$ & $40(1.23)$ \\
\hline $\begin{array}{l}\text { Liocranidae } \\
\text { (+Phrurolithus })\end{array}$ & $29(1.03)$ & $36(1.11)$ \\
\hline Zodariidae & $23(0.81)$ & $26(0.80)$ \\
\hline Pholcidae & $18(0.64)$ & $22(0.68)$ \\
\hline Hahniidae & $17(0.60)$ & $21(0.65)$ \\
\hline Titanoecidae & $19(0.67)$ & $20(0.62)$ \\
\hline Cybaeidae & $6(0.21)$ & $15(0.46)$ \\
\hline Nesticidae & $13(0.46)$ & $14(0.43)$ \\
\hline Nemesiidae & $11(0.39)$ & $13(0.40)$ \\
\hline Pisauridae & $12(0.42)$ & $12(0.37)$ \\
\hline Amaurobiidae & $8(0.28)$ & $10(0.31)$ \\
\hline others & 101 & 110 \\
\hline TOTAL & 2,827 & 3,249 \\
\hline
\end{tabular}


Table 2. Spider species composition in the FSU and post-Soviet republics, data for 1989, 1996, 2000, 2008, and 2009.

Таблица 2. Видовой состав фауны пауков всей территории и отдельных республик бывшего СССР, данные 1989 ,

1996, 2000, 2008 и 2009 гг.

\begin{tabular}{|l|c|c|c|c|c|}
\hline Regions/Years & $\mathbf{1 9 8 9}$ & $\mathbf{1 9 9 6}$ & $\mathbf{2 0 0 0}$ & $\mathbf{2 0 0 8}$ & $\mathbf{2 0 0 9}$ \\
\hline Ex-USSR & 2,184 & 2,694 & 2,827 & 3,213 & 3,249 \\
\hline Russia & & 1,874 & 1,974 & 2,260 & 2,297 \\
\hline Estonia & & 506 & 509 & 505 & 507 \\
\hline Latvia & & 401 & 402 & 414 & 415 \\
\hline Lithuania & 241 & 271 & 385 & 392 \\
\hline Byelorus(sia) & & 383 & 412 & 418 & 421 \\
\hline Ukraine & & 808 & 830 & 936 & 958 \\
\hline Moldova & 291 & 292 & 292 & 292 \\
\hline Georgia & & 326 & 456 & 463 & 467 \\
\hline Azerbaijan & 500 & 559 & 642 & 644 \\
\hline Armenia & & 118 & 127 & 134 & 135 \\
\hline Kazakhstan & & 679 & 719 & 819 & 847 \\
\hline Uzbekistan & & 290 & 309 & 320 & 321 \\
\hline Turkmenistan & & 353 & 377 & 387 & 387 \\
\hline Kyrgyzstan & & 358 & 464 & 474 & 476 \\
\hline Tadjikistan & & 293 & 310 & 316 & 317 \\
\hline
\end{tabular}

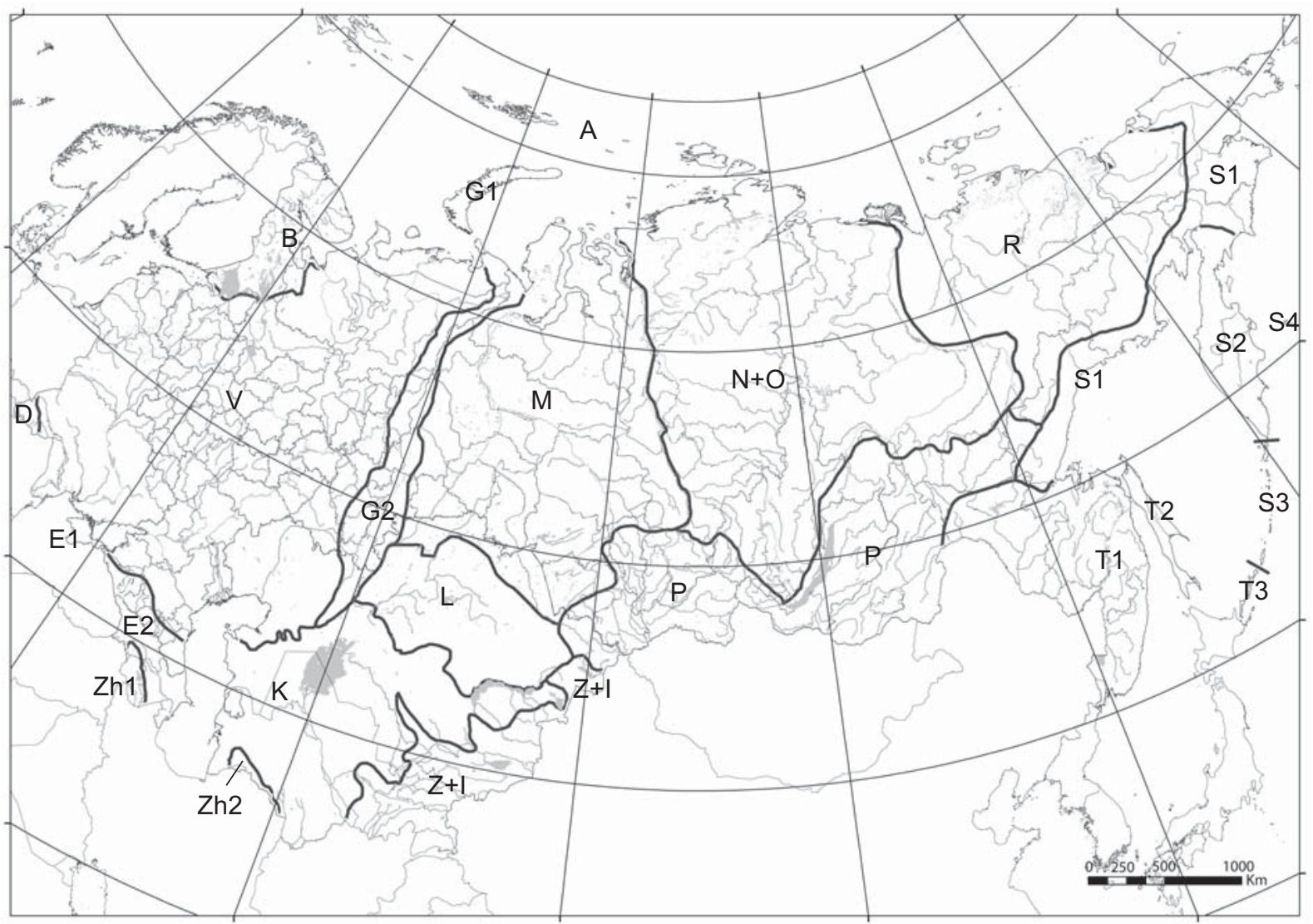

Fig. 1. Physiographical areas of the FSU (after Gvozdetsky [1968]). A — Atlantic-Arctic area, B (Б) — Fennoscandia, V (B) Russian Plain, G1 (Г1) - Novaya Zemlya, G2 (Г2) - Urals, D (Д) - Carpathians, E1 - Crimea, E2 - Caucasus, Zh1 (Ж1) Armenian Upland, Zh2 (Ж2) - Kopetdagh Mts., Z+I (3+И) - Mountains of Middle (= Central) Asia, K — Deserts of Middle (=Central) Asia, L (Л) - Kazakhstan hills, M - West Siberia, N+O (H+O) - Middle Siberia, P (П) - Mountains of South Siberia, R (P) Northeastern Siberia, S1 (C1) - Continental Far North-East, S2 (C2) - Kamchatka, S3 (C3) - N-Kuriles, S4 (C4) - Commander Islands, T1 - Continental southern Far East, T2 - Sakhalin, T3 - S-Kuriles.

Рис. 1. Физико-географические области бывшего СССР (по: Гвоздецкий, 1968). А - Атлантико-Арктическая область, В (Б) Фенноскандия, V (В) - Русская равнина, G1 (Г1) - Новая Земля, G2 (Г2) - Урал, D (Д) - Карпаты, Е1 - Крым, Е2 - Кавказ, Zh1 (Ж1) - Армянское нагорье, Zh2 (Ж2) - Копедаг, Z+I (3+И) - горы Средней Азии, K - пустыни Средней Азии, L (Л) Казахстанский мелкосопочник, $\mathrm{M}$ - Западная Сибирь, $\mathrm{N}+\mathrm{O}(\mathrm{H}+\mathrm{O})-$ Средняя Сибирь, $\mathrm{P}(\Pi)-$ горы Южной Сибири, $\mathrm{R}(\mathrm{P})-$ Северо-восточная Сибирь, S1 (C1) - континентальный Дальний Северо-Восток, S2 (C2) - Камчатка, S3 (C3) - Северные Курилы, S4 (C4) - Командорские о-ва, Т1 - континентальный юг Дальнего Востока, Т2 - Сахалин, Т3 - Южные Курилы. 
Table 3. Spider species composition in the FSU physiographical areas, data for 1989, 1996, 2000, 2008, and 2009. Таблица 3. Видовой состав фауны пауков физико-географических областей бывшего СССР, данные 1989, 1996, 2000,2008 и 2009 гг.

\begin{tabular}{|c|c|c|c|c|c|}
\hline Regions/Years & 1989 & 1996 & 2000 & 2008 & 2009 \\
\hline $\mathbf{A}$ & 1 & 1 & 2 & 2 & 2 \\
\hline B & 385 & 429 & 516 & 532 & 534 \\
\hline $\mathbf{V}$ & 936 & 1,001 & 1,026 & 1,294 & 1,314 \\
\hline G1+G2 & 600 & & & & \\
\hline G1 & & 21 & 21 & 20 & 24 \\
\hline G2 & & 683 & 750 & 786 & 790 \\
\hline D & 435 & 421 & 428 & 459 & 485 \\
\hline E1 & 308 & 311 & 342 & 478 & 500 \\
\hline E2+Zh1 & 671 & & & & \\
\hline E2 & & 752 & 834 & 927 & 940 \\
\hline Zh1 & & 127 & 135 & 228 & 231 \\
\hline Zh2 & & 221 & 240 & 243 & 244 \\
\hline $\mathbf{Z}+\mathbf{I}$ & & 773 & 833 & 878 & 880 \\
\hline $\mathbf{K}$ & 291 & 318 & 338 & 352 & 360 \\
\hline $\mathbf{L}$ & 103 & 129 & 143 & 160 & 160 \\
\hline M & 243 & 440 & 554 & 602 & 652 \\
\hline $\mathbf{N}+\mathbf{O}$ & 532 & 624 & 634 & 667 & 666 \\
\hline $\mathbf{P}$ & 436 & 813 & 912 & 1,002 & 1,015 \\
\hline $\mathbf{R}$ & 277 & 395 & 397 & 408 & 408 \\
\hline $\mathrm{S} 1+\mathrm{S2}+\mathrm{S3}+\mathrm{S4}$ & 278 & & & & \\
\hline S1 & & 411 & 415 & 446 & 451 \\
\hline S2 & & 184 & 182 & 204 & 205 \\
\hline S3 & & 54 & 60 & 81 & 81 \\
\hline S4 & & 19 & 20 & 20 & 20 \\
\hline T1+T2+T3 & 375 & & & & \\
\hline T1 & & 507 & 566 & 797 & 843 \\
\hline T2 & & 343 & 338 & 361 & 361 \\
\hline T3 & & 144 & 149 & 165 & 166 \\
\hline
\end{tabular}

Regions: A — Atlantic-Arctic area, B (Б) — Fennoscandia, V (B) — Russian Plain, G1 (Г1) — Novaya Zemlya, G2 (Г2) — Urals, D (Д) - Carpathians, E1 - Crimea, E2 - Caucasus, Zh1 (Ж1) - Armenian Upland, Zh2 (Ж2) - Kopetdagh Mts., Z+I (3+И) Mountains of Middle (=Central) Asia, K - Deserts of Middle (=Central) Asia, L (Л) - Kazakhstan hills, M - West Siberia, N+O (H+O) Middle Siberia, P (П) - Mountains of South Siberia, R (P) - Northeastern Siberia, S1 (C1) - Continental Far North-East, S2 (C2) Kamchatka, S3 (C3) - N-Kuriles, S4 (C4) - Commander Islands, T1 - Continental southern Far East, T2 - Sakhalin, T3 - S-Kuriles.

was 510 during 1989-1995, i.e. approximately 73 species annually. In 1996-2000, these values were 130 and 33 , versus 422 and 47 in 2001-2009, respectively.

The main spider families treated here (Table 1) are represented in 2009 by 10 or more species. Linyphiidae show the highest diversity, as usual. Gnaphosidae and Salticidae share the second and third places (vice versa in 2000, but the same in 1996 and 1989, see Mikhailov, 2002).

An analysis of the spider fauna of the post-Soviet republics (Table 2) reveals almost the same patterns as earlier: Russia supports the highest diversity (2,297 species), followed by Ukraine, Kazakhstan, and Azerbaijan (958, 847, and 644 species, respectively). The spider faunas of Moldova and Armenia are still insufficiently well studied. In Lithuania, more than 100 species have been recorded since 2000 , the fauna having become similar to the Latvian one in species richness. The main increase in species in 2000-2009 concerns Russia $(+323$ species), Ukraine $(+128)$, Kazakhstan $(+128)$, Lithuania $(+121)$, and Azerbaijan $(+85)$, but not Georgia or Kyrgyzstan, as noted for 1996-2000 [Mikhailov, 2002]. Only small changes can be documented for Estonia, Latvia, Byelorussia, Moldova, Georgia, Armenia, and Middle (= Central) Asian republics. As compared to 1996-2000, in 2001-2009 the activities of local arachnologists increased only in Russia, Lithuania, Ukraine and Azerbaijan (together with foreign specialists in the latter case). Most of the contributions to the spider fauna of Kazakhstan belong to foreign, non-Kazakhstan araneologists.

The division of the FSU territory into physiographical areas is accepted according to Gvozdetsky [1968] (Fig. 1).

The main increase during 2000-2009 is reported from the Russian Plain (V, +288 species, or $28.1 \%$ of the 2000 number), continental southern Far East (T1, +277 species, or $48.94 \%$ ), Crimea (E1, +158 species, or $46.2 \%$ ), Caucasus (E2, +106 species, or $12.71 \%$ ), the mountains of South Siberia (P, +103 species, or $11.29 \%$ ), West Siberia (M, +98 species, or $17.69 \%$ ) (see Table 3). Crucial contributions have been made in 
the continental southern Far East (Russia), yet mostly by extra-regional arachnologists, as opposed to the Crimea (Ukraine) which has been worked out by regional specialists. Earlier, during 1996-2000, the main progress was made in West Siberia (M, 29.91\% of the 1996 number), Fennoscandia (B, 20.28\%), the mountains of South Siberia (P, 12.18\%), the Far East (T1, $11.64 \%)$

Earlier evaluations of the total FSU spider fauna were at 2,700-3,000 species [Mikhailov, 1992], increased to 3,400-3,500 species [Mikhailov, 1997]. Current data allow me to increase the estimated number to 3,700-3,800 species in the FSU, including 2,500-2,600 species in Russia. Faunistic studies on the spiders of Russia and the FSU are still incomplete and go on.

ACKNOWLEDGEMENTS. I am deeply obliged to Sergei Golovatch (Moscow, Russia) who kindly checked the English of an advanced draft.

\section{References}

Charitonov D.E. 1932. Katalog der russischen Spinnen. Leningrad: AN SSSR Publ. 206 S. [bilingual, in Russian and German]
Charitonov D.E. 1946. [Addition to the catalogue of Russian spiders] // Uchenye zapiski Permskogo Univ. Vol.2. No.1. P.167225 [in Russian, with German summary]

Gvozdetsky N.A. 1968. [A physiographical regionalization of the USSR]. Moscow: MGU Publ. 576 p., 1 map [in Russian].

Mikhailov K.G. 1992. [Results of the study of the USSR spider fauna] // V.I. Ovtsharenko (ed.). Fauna i ekologiya paukov, skorpionov i lozhnskorpionov SSSR. Trudy Zoologicheskogo Instituta AN SSSR. Vol.226 (for 1990). P.127-129 [in Russian].

Mikhailov K.G. 1997. Catalogue of the spiders of the territories of the former Soviet Union (Arachnida, Aranei) // Sbornik trudov Zoologicheskogo Muzeya MGU (=Archives of the Zoological Museum of the Moscow State University). Vol.37. 416 p.

Mikhailov K.G. 1998. Catalogue of the spiders (Arachnida, Aranei) of the territories of the former Soviet Union. Addendum 1. Moscow: KMK Sci. Press. 50 p.

Mikhailov K.G. 1999. Catalogue of the spiders (Arachnida, Aranei) of the territories of the former Soviet Union. Addendum 2. Moscow: Zoological Museum MGU. 39 p.

Mikhailov K.G. 2000. Catalogue of the spiders (Arachnida, Aranei) of the territories of the former Soviet Union. Addendum 3. Moscow: Zoological Museum MGU. 33 p.

Mikhailov K.G. 2002. The spider fauna of Russia and other postSoviet republics: a 2000 update // S. Toft, N. Scharff (eds.). European Arachnology 2000. Proc. 19 ${ }^{\text {th }}$ Europ. Colloq. of Arachnology, Århus 17-22 July 2000. Århus. P.255-259.

Mikhailov K.G. 2011. [The spider fauna of Russia and adjacent territories: advances in the study] // B.R. Striganova (ed.). Problemy pochvennoi zoologii (Materialy XVI Vserossiyskogo soveshchaniya po pochvennoi zoologii). Moscow: KMK Sci. Press. P.83 [in Russian]. 